\title{
PENGARUH SUHU KALSINASI PADA PROSES DEKOMPOSISI DOLOMIT
}

\author{
Ahmad Royani, Eko Sulistiyono dan Deddy Sufiandi \\ Pusat Penelitian Metalurgi dan Material - LIPI \\ Kawasan Puspiptek, Serpong 15314, Tangerang Selatan \\ E-mail: ahmad.royani@lipi.go.id
}

\begin{abstract}
ABSTRAK
PENGARUH SUHU KALSINASI PADA PROSES DEKOMPOSISI DOLOMIT. Proses dekomposisi dolomit menjadi $\mathrm{MgO}$ dan $\mathrm{CaO}$ merupakan proses penting mengingat kedua oksida tersebut banyak digunakan dalam berbagai aplikasi. Untuk melihat pengaruh suhu proses kalsinasi terhadap dekomposisi dolomit menjadi $\mathrm{MgO}$ dan $\mathrm{CaO}$, maka dilakukan kalsinasi. Proses kalsinasi menggunakan tungku Muffle furnace dengan suhu sebesar $500{ }^{\circ} \mathrm{C}, 600^{\circ} \mathrm{C}, 700^{\circ} \mathrm{C}, 800$ dan $900^{\circ} \mathrm{C}$. Sebanyak kurang lebih $100 \mathrm{gram} / \mathrm{sampel}$ dolomit dimasukkan dalam tungku dan dipanaskan dengan laju pemanasan $10^{\circ} \mathrm{C} /$ menit pada berbagai suhu yang kemudian ditahan masing-masing selama 1 jam, 2 jam, 3 jam, 4 dan 5 jam. Produk kalsinasi kemudian ditimbang dan dikarakterisasi dengan X-Ray Diffraction (XRD) dan Scanning Electron Microscope (SEM). Hasil percobaan menunjukkan kalsinasi dolomit semakin meningkat seiring dengan kenaikkan suhu kalsinasi. Proses kalsinasi dolomit optimum tercapai pada suhu $900^{\circ} \mathrm{C}$ selama 4 jam dengan pengurang berat mencapai $46,74 \%$. Berdasarkan perhitungan stoikiometri pengurangan berat $46,74 \%$ menunjukkan bahwa 97,78 \% dolomit terdekomposisi menjadi $\mathrm{MgO}$ dan $\mathrm{CaO}$. Pembentukan fasa $\mathrm{MgO}$ dan $\mathrm{CaO}$ dari dolomit melalui dua tahapan yaitu tahapan pembentukan fasa $\mathrm{MgO}-\mathrm{CaCO}_{3}$ pada suhu $700{ }^{\circ} \mathrm{C}$ dan tahapan pembentukan $\mathrm{CaO}$ pada suhu $800{ }^{\circ} \mathrm{C}-900^{\circ} \mathrm{C}$. Kesimpulan yang didapatkan dari proses kalsinasi dolomit ini adalah peningkatan suhu kalsinasi dapat meningkatkan proses dekomposisi dolomit menjadi fasa $\mathrm{MgO}$ dan $\mathrm{CaO}$.
\end{abstract}

Kata kunci: Dekomposisi, Kalsinasi, Dolomit, Perubahan fasa

\begin{abstract}
THE EFFECT OF CALCINATION TEMPERATURE ON THE DECOMPOSITION OF DOLOMITE. Decomposition of dolomite to $\mathrm{MgO}$ and $\mathrm{CaO}$ is important because both these oxides are widely used in various applications. To determine the effect of calcination temperature on the decomposition of dolomite to $\mathrm{MgO}$ and $\mathrm{CaO}$, the calcination was investigated. The Muffle furnace was used to calcination process at temperatures of $500,600,700,800$ and $900{ }^{\circ} \mathrm{C}$. A total of dolomite (100 gram) was put in a furnace and heated with a heating rate of $10^{\circ} \mathrm{C} / \mathrm{min}$ at various temperatures and then arrested with holding time 1,2 , 3, 4 and 5 hours, respectively. The calcined samples were then weight measured and characterized by X-Ray Diffraction (XRD) and Scanning Electron Microscope (SEM). The experimental results indicated that the decomposition of dolomite increases with the increases of the calcination temperature. The optimum calcination conditions are achieved at $900{ }^{\circ} \mathrm{C}$ for 4 hours. Under the optimum conditions, the weight loss of dolomite can reach $46.74 \%$. Based on stoichiometry calculations $46.74 \%$ weight reduction showed that $97.78 \%$ of dolomite decomposed into $\mathrm{MgO}$ and $\mathrm{CaO}$. The decomposition of dolomite into $\mathrm{CaO}$ and $\mathrm{MgO}$ through two stages, namely stages of formation of $\mathrm{MgO}-\mathrm{CaCO}_{3}$ at $700{ }^{\circ} \mathrm{C}$ and $\mathrm{CaO}$ at $800{ }^{\circ} \mathrm{C}-900{ }^{\circ} \mathrm{C}$. The conclusions obtained from this calcination of dolomite is the raising of calcination temperature can improve the process of decomposition of dolomite into $\mathrm{MgO}$ and $\mathrm{CaO}$.
\end{abstract}

Keywords: Decomposition, Calcination, Dolomite, Phase transformation 


\section{PENDAHULUAN}

Dolomit merupakan batuan sedimen alami yang termasuk rumpun mineral karbonat [1,2]. Mineral dolomit murni secara teoritis mengandung $45,6 \% \mathrm{MgCO}_{3}$ atau $21,9 \% \mathrm{MgO}$ dan $54,3 \% \mathrm{CaCO}_{3}$ atau $30,4 \% \mathrm{CaO}$. Rumus kimia mineral dolomit dapat ditulis meliputi $\mathrm{CaCO}_{3} \cdot \mathrm{MgCO}_{3}, \mathrm{CaMg}\left(\mathrm{CO}_{3}\right)_{2}$ atau $\mathrm{Ca}_{\mathrm{x}} \mathrm{Mg}_{1-\mathrm{x}} \mathrm{CO}_{3}$, dengan nilai $x$ lebih kecil dari satu [3]. Potensi dolomit di Indonesia cukup besar dan terbesar ditemukan mulai dari propinsi di Aceh hingga ke Papua dengan spesifikasi yang berbeda-beda. Di alam, dolomit jarang ditemukan dengan komposisi murni, karena umumnya mineral ini selalu terdapat bersama-sama (bercampur) dengan batu gamping, kwarsa, rijang, pirit, lempung dan pengotor lainnya. Dolomit merupakan mineral gabungan dari dua karbonat yakni magnesium karbonat $\left(\mathrm{MgCO}_{3}\right)$ dan kalsium karbonat $\left(\mathrm{CaCO}_{3}\right)$. Dolomit dapat berdekomposisi menjadi senyawa oksida berupa $\mathrm{MgO}$ dan $\mathrm{CaO}$ yang banyak digunakan pada berbagai aplikasi di industri [4-6]. $\mathrm{MgO}$ dapat digunakan sebagai bahan bata tahan api tahan suhu tinggi, bahan campuran semen, industri medis, bahan pembuatan pupuk dan sebagai bahan isolator. Sedangkan $\mathrm{CaO}$ banyak digunakan dalam industri pembuatan semen dan bahan industri kimia untuk pembuatan senyawa tertentu $[5,6]$. Dengan demikian proses dekomposisi dolomit menjadi $\mathrm{MgO}$ dan $\mathrm{CaO}$ merupakan proses penting walaupun membutuhkan energi dan bersifat endotermik.

Proses dekomposisi dolomit menjadi $\mathrm{MgO}$ dan $\mathrm{CaO}$ sudah banyak dilakukan baik secara isothermal maupun non-isothermal [7-12]. Variabel proses sangat berpengaruh terhadap pembentukan kurva dan puncak fasa $\mathrm{MgO}$ dan $\mathrm{CaO}$. Peningkatan laju pemanasan dekomposisi menyebabkan peningkatan ketinggian puncak dari $\mathrm{MgO}$ dan $\mathrm{CaO}$ [7]. Mekanisme dekomposisi parsial $\mathrm{MgO}$ dari dolomit bermula dari lepasnya gas $\mathrm{CO}_{2}$ dan terbentuknya ion $\mathrm{O}^{2-}$ pada permukaan dolomit. Kemudian $\mathrm{Mg}^{2+}$ bergerak menuju $\mathrm{O}^{2-}$ sedangkan $\mathrm{Ca}^{2+}$ bermigrasi membentuk $\mathrm{CaCO}_{3}$ pada permukaan dolomit [8]. Pada penelitian kalsinasi dolomit alam menggunakan gas argon pada tekanan atmosfir, dekomposisi menjadi $\mathrm{MgO}$ dan $\mathrm{CaCO}_{3}$ terjadi pada suhu $700{ }^{\circ} \mathrm{C}$ kemudian $\mathrm{CaCO}_{3}$ berdekomposisi menjadi $\mathrm{CaO}$ pada suhu $700{ }^{\circ} \mathrm{C}$ hingga $900{ }^{\circ} \mathrm{C}$ [9]. Bentuk kristalin $\mathrm{CaO}$ dan $\mathrm{MgO}$ dapat dihasilkan dari dolomit melalui dua tahapan kalsinasi dalam gas $\mathrm{CO}_{2}$ dan $\mathrm{N}_{2}$ [10]. Penelitian dekomposisi pada dolomit palygorskite-China (DPC), suhu dekomposisi dolomit ditemukan $50^{\circ} \mathrm{C}$ lebih rendah dari dolomit umum. Dekomposisi dolomit mulai terjadi pada suhu $500{ }^{\circ} \mathrm{C}$ dan berakhir pada $780{ }^{\circ} \mathrm{C}$ dengan puncak maksimum terdapat pada suhu $745^{\circ} \mathrm{C}$ [13]. Proses dekomposisi magnesium karbonat terjadi pada suhu lebih rendah dari pada proses dekomposisi kalsium karbonat [14]. Fasa $\mathrm{MgO}$ terdekomposisi dari dolomit dan memisah padasuhu kalsinasi $850{ }^{\circ} \mathrm{C}$ [15]. Terbentuknya $\mathrm{MgO}$ pada proses dekomposisi magnesium karbonat melalui dua tahap yakni proses dehidrasi dan pembentukan $\mathrm{MgO}$ [16]. Proses dekomposisi dolomit juga dipengaruhi oleh komposisi kandungan dari $\mathrm{CaCO}_{3}$ dan $\mathrm{MgCO}_{3}$. Penelitian mengenai pengaruh komposisi menyebutkan energi aktivasi meningkat $1,309 \mathrm{~kJ} / \mathrm{mol}$ untuk setiap penambahan persen berat dari $\mathrm{CaCO}_{3}[17]$.

Di Indonesia, Proses kalsinasi terhadap dolomit juga pernah dilakukan oleh Eko dkk. Penelitiannya difokuskan pada pengamatan terhadap ukuran dari dolomit itu sendiri. Hasil percobaannya menyebutkan bahwa ukuran butiran dolomit berpengaruh terhadap hasil kalsinasi, semakin besar ukuran dolomit yang diproses maka reaksi kalsinasi semakin cepat [18]. Banyak yang mempengaruh keberhasilan proses dekomposisi dolomit menjadi $\mathrm{MgO}$ dan $\mathrm{CaO}$. Faktor-faktor tersebut meliputi tekanan parsial dari gas $\mathrm{CO}_{2}$, massa dolomit, laju pemanasan, suhu dan waktu proses [19].

Pada penelitian ini, dolomit alam dimodifikasi dengan proses kalsinasi pada berbagai suhu dan waktu. Untuk melihat pengaruh suhu dan waktu proses kalsinasi terhadap dekomposisi dolomit, maka suhu kalsinasi divariasikan dari 500 hingga $900{ }^{\circ} \mathrm{C}$ dan waktu kalsinasi diperpanjang dari 1 sampai 5 jam. Berdasarkan referensi yang telah disebutkan bahwa peningkatan suhu dapat mempengaruhi proses dekomposisi dolomit menjadi fasa $\mathrm{MgO}$ dan $\mathrm{CaO}$. Tujuan penelitian ini adalah untuk mengetahui pengaruh suhu kalsinasi dalam proses dekomposisi dolomit menjadi fasa $\mathrm{MgO}$ dan $\mathrm{CaO}$. Proses kalsinasi yang sederhana diharapkan mampu membentuk fasa $\mathrm{MgO}$ dan $\mathrm{CaO}$ dari dolomit sehingga dapat dimanfaatkan untuk keperluan berbagai aplikasi di industri.

\section{METODE PERCOBAAN}

\section{Bahan dan Alat}

Bahan yang digunakan meliputi serbuk dolomit dari daerah Jawa Timur (PT. XYZ) dengan komposisi kimia seperti pada Tabel 1. Pola difraksi sinar-X untuk dolomit digambarkan pada Gambar 1.

Proses kalsinasi menggunakan tungku Muffle furnace (Carbolite-CWF 1300, England). Karakterisasi sampel dolomit dan produk kalsinasi menggunakan difraksi sinar-X (Shimadzu XRD 7000) untuk mengetahui fasa-fasa yang terkandung dalam dolomit dan hasil proses dekomposisi. XRF (JEOL Element Analizer

Tabel 1. Analisis komposisi kimia dolomit dengan $X R F$

\begin{tabular}{lcc}
\hline No & Senyawa & \% Berat \\
\hline 1. & $\mathrm{CaO}$ & 61,38 \\
2. & $\mathrm{MgO}$ & 25,73 \\
3. & $\mathrm{Na}_{2} \mathrm{O}$ & 7,93 \\
4. & $\mathrm{SiO}_{2}$ & 1,19 \\
5. & $\mathrm{Al}_{2} \mathrm{O}_{3}$ & 0,84 \\
6. & $\mathrm{P}_{2} \mathrm{O}_{5}$ & 0,54 \\
7. & $\mathrm{SO}_{3}$ & 0,41 \\
8. & $\mathrm{K}_{2} \mathrm{O}$ & 0,40 \\
9. & $\mathrm{Fe}_{2} \mathrm{O}_{3}$ & 0,37 \\
\hline
\end{tabular}




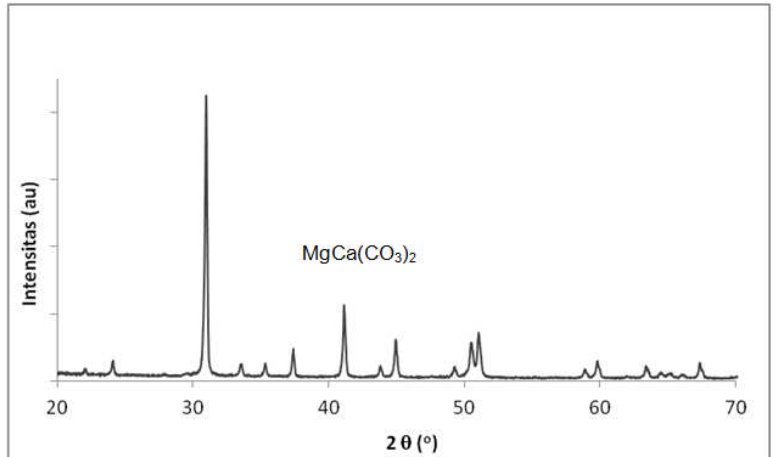

Gambar 1. Pola difraksi sinar-X dolomit.

JSX -3211) untuk analisa komposisi kimia mineral dolomit dan Scanning Electron Microscope (SEM) JEOL JSM-6390A untuk analisis struktur mikro dan morfologi partikel.

\section{Cara Kerja}

Bijih dolomit digerus sehingga berukuran kurang dari 60 mesh kemudian dikeringkan dalam oven pada suhu $100{ }^{\circ} \mathrm{C}$ selama 7 jam. Setiap sampel sebanyak 100 gram serbuk dolomit dimasukkan dalam tungku dan dipanaskan dengan laju pemanasan $10{ }^{\circ} \mathrm{C} /$ menit pada berbagai suhu. Suhu proses kalsinasi divariasikan dari $500{ }^{\circ} \mathrm{C}$ hingga $900{ }^{\circ} \mathrm{C}$. Setelah suhu proses kalsinasi tercapai kemudian ditahan selama 1 jam hingga 5 jam untuk setiap variasi suhu. Produk kalsinasi kemudian ditimbang dan dikarakterisasi menggunakan difraksi sinar-X dan Scanning Electron Microscope (SEM).

\section{HASIL DAN PEMBAHASAN}

\section{Karakteristik Sampel Dolomit}

Dolomit yang digunakan dari daerah Jawa Timur mempunyai komponen utama $\mathrm{CaO}$ dan $\mathrm{MgO}$ sebesar $61,38 \%$ dan $25,73 \%$ serta unsur pengotor lainnya seperti yang ditunjukkan dalam hasil analisis XRF pada Tabel 1 . Pada analisa dolomit awal dengan menggunakan difraksi sinar-X (Gambar 1), terlihat sangat jelas bahwa puncak menunjukkan mineral dolomit dan tidak ditemukan puncak unsur-unsur pengotor dikarenakan kandungannya yang kecil. Hasil SEM-Mapping dolomit ditunjukkan pada Gambar 2. Dari Gambar 2 tersebut, dapat dilihat bahwa sebaran unsur $\mathrm{Ca}, \mathrm{Mg}, \mathrm{O}$ serta $\mathrm{C}$ yang ditandai dengan warna merah hampir merata dan berada pada seluruh permukaan yang menyatakan mineral dolomit. Sedangkan unsur pengotor seperti Fe, Si dan Al tidak terlihat.

\section{Proses Kalsinasi}

Hasil proses kalsinasi dolomit pada berbagai suhu terhadap waktu ditunjukkan pada Gambar 3. Gambar 3 menunjukkan peningkatan fasa terdekomposisi atau
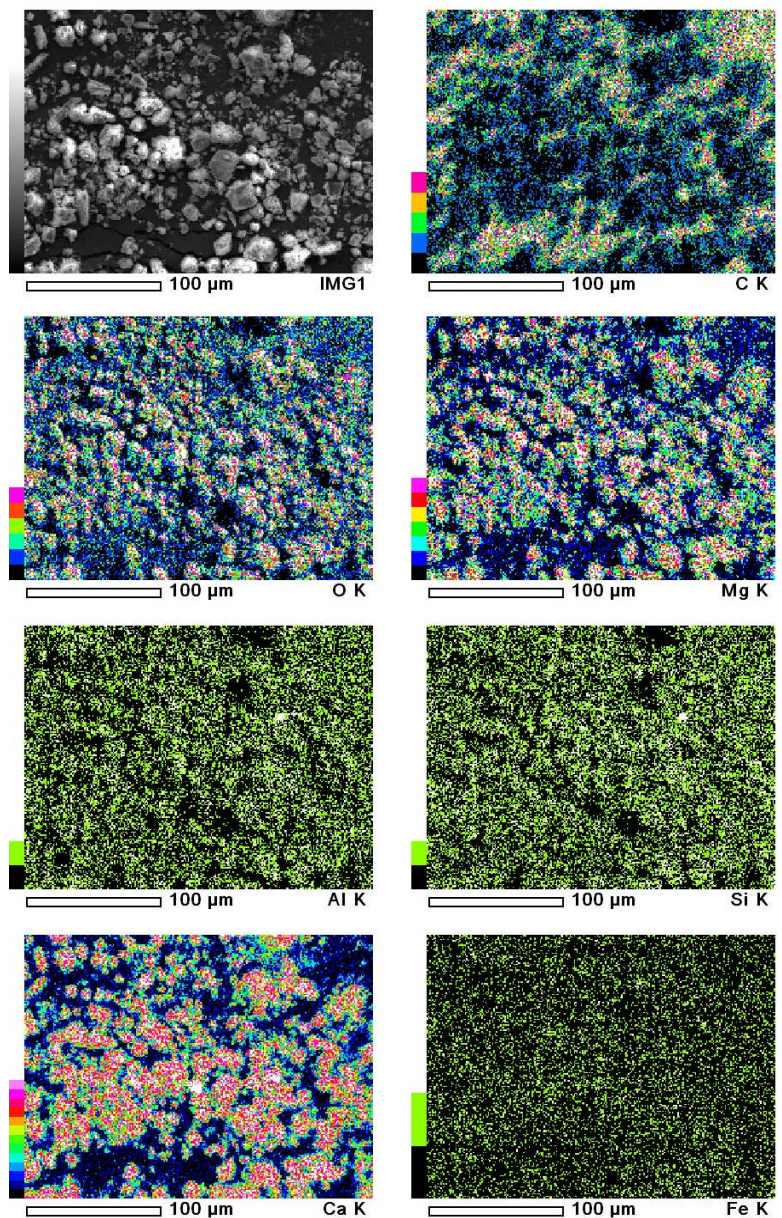

Gambar 2. Hasil SEM-Mapping Dolomit.

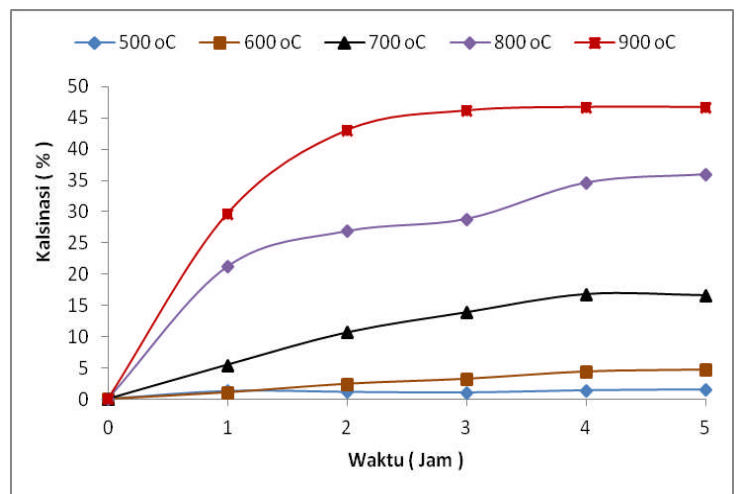

Gambar 3. Grafik hubungan persen kalsinasi dan waktu pada berbagai suhu.

persen kalsinasi selama proses pemanasan. Persen kaslinasi (fasa terdekomposisi) dihitung dari perubahan berat sampel terhadap berat awal karena berat yang hilang berupa gas $\mathrm{CO}_{2}$ yang secara teoritik maskimal sebesar 47,8 \%. Dapat dilihat bahwa persen kalsinasi maksimum dicapai pada suhu $900{ }^{\circ} \mathrm{C}$ yakni mencapai $46,74 \%$ atau setara dengan $97,78 \%$ dari teoritik. Pada suhu $900{ }^{\circ} \mathrm{C}$ tersebut, dapat dikatakan bahwa telah terjadi proses dekomposisi dolomit menjadi $\mathrm{MgO}$ dan $\mathrm{CaO}$ secara total karena $\mathrm{MgCa}\left(\mathrm{CO}_{3}\right)_{2}$, hampir terdekomposisi 


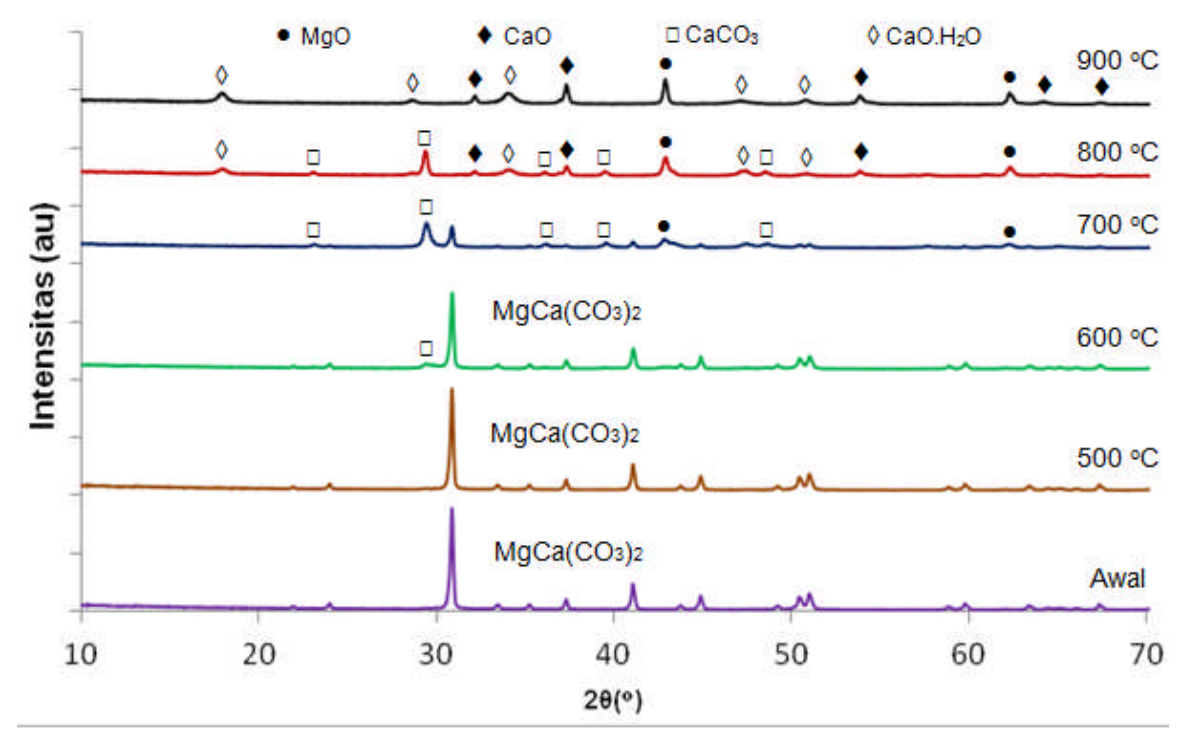

Gambar 4. Pola Difraksi Sinar-X Hasil Dekomposisi

secara sempurna (97,78\%) menjadi $\mathrm{MgO}$ dan $\mathrm{CaO}$. Hasil ini sesuai dengan yang dilakukan oleh P. Engler, dkk yang menyatakan bahwa proses dekomposisi total dolomit terjadi pada suhu $900-960{ }^{\circ} \mathrm{C}$ [20].

Selanjutnya pada suhu rendah reaksi cenderung berjalan lambat sehingga proses dekomposisi dolomit menjadi $\mathrm{MgO}$ dan $\mathrm{CaO}$ membutuhkan waktu yang panjang. Dapat dibandingkan bahwa pada suhu $500{ }^{\circ} \mathrm{C}$ hanya 1,6\% fasa yang terdekomposisi menjadi $\mathrm{MgO}$ dan $\mathrm{CaO}$ selama 5 jam sedangkan pada suhu $900{ }^{\circ} \mathrm{C}$ hampir keseluruhan terdekomposisi menjadi $\mathrm{MgO}$ dan $\mathrm{CaO}$.

\section{Pembentukan Fasa MgO dan CaO}

Hasil analisis difraksi sinar-X terhadap dolomit setelah dilakukan proses kalsinasi dalam berbagai suhu ditunjukkan dalam Gambar 4. Pada suhu $500{ }^{\circ} \mathrm{C}$ dan $600{ }^{\circ} \mathrm{C}$, belum ditemukan puncak $\mathrm{MgO}$ ataupun $\mathrm{CaCO}_{3}$. Namun, pada $600{ }^{\circ} \mathrm{C}$ mulai muncul puncak $\mathrm{CaCO}_{3}$ di sudut 2 pada posisi sudut $29,42^{\circ}$. Sedangkan pada suhu $700{ }^{\circ} \mathrm{C}$, mulai terbentuk fasa $\mathrm{MgO}$ pada sudut 2 diposisi $42,94^{\circ}$ dan $62,35^{\circ}$ serta fasa $\mathrm{CaCO}_{3}$ yang semakin banyak.

Hasil analisis difraksi sinar-X menyatakan bahwa proses dekomposisi dolomit menjadi $\mathrm{MgO}$ dan $\mathrm{CaCO}_{3}$ mulai terbentuk pada suhu $700{ }^{\circ} \mathrm{C}$. Pada suhu rendah (kurang dari $700{ }^{\circ} \mathrm{C}$ ) puncak fasa $\mathrm{MgO}$ belum terbentuk dan masih sama seperti kondisi awal. Dari hasil analisis difraksi sinar-X juga dapat dijelaskan bahwa proses dekomposisi fasa dolomit $\left(\mathrm{MgCa}\left(\mathrm{CO}_{3}\right)_{2}\right)$ menjadi $\mathrm{MgO}$ dan $\mathrm{CaCO}_{3}$ mulai terjadi pada $700{ }^{\circ} \mathrm{C}$. Hasil ini sesuai dengan yang dilakukan oleh K. Sasaki et al, yang menyatakan proses dekomposisi dolomit menjadi $\mathrm{MgO}$ mulai terjadi pada $700{ }^{\circ} \mathrm{C}[9]$.

Pada suhu $800^{\circ} \mathrm{C}$ dan $900{ }^{\circ} \mathrm{C}$, fasa $\mathrm{MgO}$ dan $\mathrm{CaO}$ sudah sangat jelas dan puncak-puncaknya juga semakin banyak. Hal ini terjadi karena pada suhu tersebut pembentukan $\mathrm{MgO}$ yang hampir sempurna dan senyawa kalsit $\left(\mathrm{CaCO}_{3}\right)$ mengalami dekomposisi menjadi $\mathrm{CaO}$ [14]. Pada suhu $800{ }^{\circ} \mathrm{C}$ dan $900{ }^{\circ} \mathrm{C}$, ditemukan juga fasa $\mathrm{CaO} . \mathrm{H}_{2} \mathrm{O}$. Penyebab adanya fasa $\mathrm{CaO} \cdot \mathrm{H}_{2} \mathrm{O}$ ini dimungkin karena sifatnya yang hidrokopis sehingga pada saat pendinginan atau peyimpanan terjadi reaksi dengan $\mathrm{H}_{2} \mathrm{O}$. Hasil - hasil pola difraksi sinar-X memperlihatkan bahwa mekanisme proses dekomposisi dolomit terjadi melalui dua tahapan sesuai dengan Persamaan (1) dan Persamaan (2).

$$
\begin{aligned}
& \mathrm{MgCa}\left(\mathrm{CO}_{3}\right)_{2} \longrightarrow \mathrm{MgO}+\mathrm{CaCO}_{3}+\mathrm{CO}_{2} \ldots \ldots \ldots \ldots . . . \\
& \mathrm{CaCO}_{3} \longrightarrow \mathrm{CaO}+\mathrm{CO}_{2}
\end{aligned}
$$

Reaksi pertama terjadi pada suhu sekitar $700^{\circ} \mathrm{C}$ sedangkan reaaksi kedua terjadi pada suhu diatas $800{ }^{\circ} \mathrm{C}$. Reaksi pertama disebut juga dengan proses dekomposisi parsial sedangkan reaksi kedua disebut dengan proses dekomposisi total. Hasil penelitian ini sebanding dengan yang dilakukan oleh P. Engler, dkk yang menyatakan bahwa pembentukan $\mathrm{MgO}$ terjadi antara $550{ }^{\circ} \mathrm{C}-765^{\circ} \mathrm{C}$, sedangkan $\mathrm{CaO}$ dibentuk antara $900{ }^{\circ} \mathrm{C}-960^{\circ} \mathrm{C}[20]$. Hasil penelitian ini juga sesuai dengan yang dilakukan oleh K. Sasaki, dkk yang menyatakan bahwa $\mathrm{CaCO}_{3}$ berdekomposisi menjadi $\mathrm{CaO}$ dan gas $\mathrm{CO}_{2}$ pada suhu $700{ }^{\circ} \mathrm{C}$ hingga $900{ }^{\circ} \mathrm{C}$ [9]. Pada hasil proses dekomposisi ini juga terbentuk fasa $\mathrm{Ca} \cdot \mathrm{H}_{2} \mathrm{O}$, hal ini menunjukkan bahwa fasa $\mathrm{CaO}$ sudah cukup banyak sehingga fasa $\mathrm{CaO}$ ada yang menyerap air dari udara membentuk fasa Ca. $\mathrm{H}_{2} \mathrm{O}$.

\section{Morfologi Butiran}

Hasil analisis SEM-Mapping mikro struktur butiran dolomit setelah dilakukan kalsinasi pada $900{ }^{\circ} \mathrm{C}$ selama 4 jam dilihat dalam Gambar 5. Dari hasil gambar SEM-Mapping tersebut, nampaknya unsur $\mathrm{Ca}$ 
mendominasi seluruh permukaan butiran (ditunjukkan dengan warna merah yang pekat pada Gambar 5). Sementara untuk unsur $\mathrm{Mg}$ sebaranya lebih kecil dari unsur $\mathrm{Ca}$ ( warna merah lebih sedikit dibandingkan dengan unsur $\mathrm{Ca}$ ). Secara umum dapat dilihat bahwa sebaran butiran $\mathrm{CaO}$ dan $\mathrm{MgO}$ merata keseluruhan permukaan dengan intensitas yang berbeda. Hasil analisa kualitatif $S E M-E D S$ butiran dolomit setelah dilakukan kalsinasi pada $900{ }^{\circ} \mathrm{C}$ selama 4 jam ditunjukkan dalam Gambar 6. Hasil analisa kualitatif SEM-EDS butiran dolomit setelah dilakukan kalsinasi pada suhu 900 oC selama 4 jam ditunjukkan dalam Gambar 6. Dari hasil analisa kualitatif SEM-EDS tersebut, butiran dolomit diketahui mengandung $17,47 \% \mathrm{Mg}$ dan $41,67 \% \mathrm{Ca}$ atau setara dengan 28,97\% $\mathrm{MgO}$ dan 58,34\% $\mathrm{CaO}$.
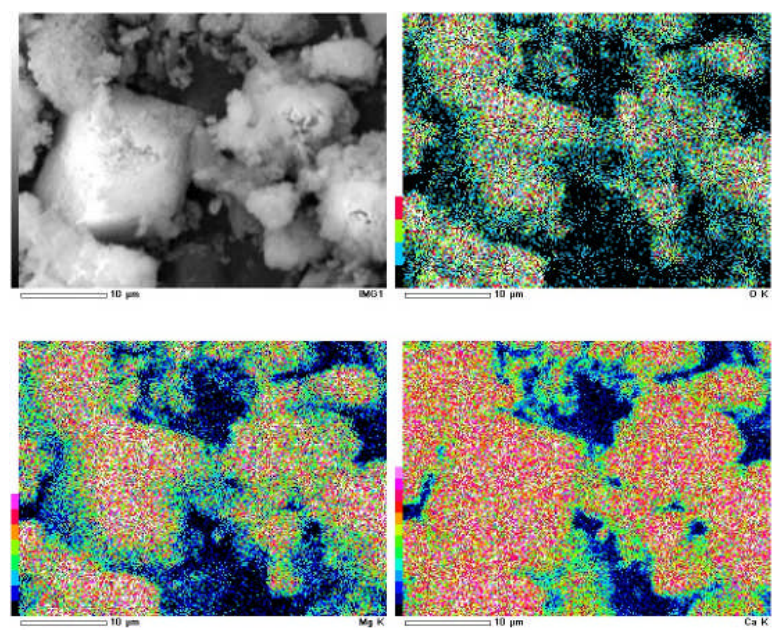

Gambar 5. Hasil Foto SEM-Mapping Dolomit pada suhu $900{ }^{\circ} \mathrm{C}$ (pembesaran 3.000X).

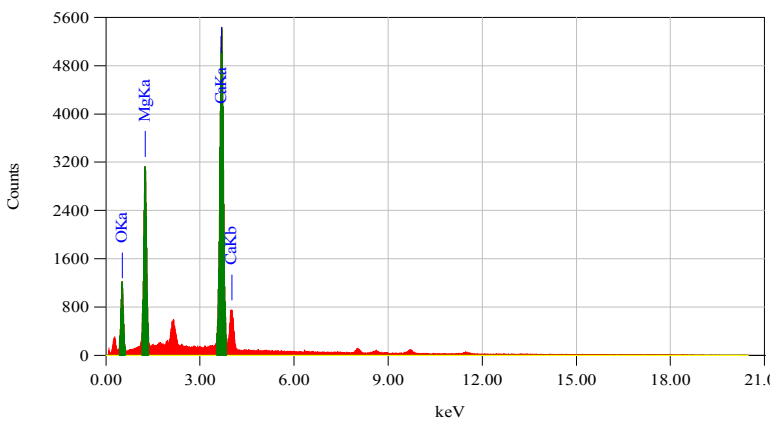

ZAF Method Standardless Quantitative Analysis Fitting Coefficient : 0.3505

\begin{tabular}{lllll}
\hline Element & $(\mathrm{keV})$ & Mass\% & Error\% & Atom\% \\
\hline O K & 0.525 & 40.86 & 0.76 & 59.22 \\
Mg K & 1.253 & 17.47 & 0.23 & 16.67 \\
Ca K & 3.690 & 41.67 & 0.26 & 24.11 \\
\hline Total & & 100.00 & & 100.00 \\
\hline
\end{tabular}

Gambar 6. Hasil Foto SEM-EDS Dolomit pada suhu $900{ }^{\circ} \mathrm{C}$

\section{KESIMPULAN}

Proses pembentukan fasa $\mathrm{MgO}$ dan $\mathrm{CaO}$ dari dolomit dapat dilakukan melalui proses kalsinasi. Proses kalsinasi dolomit berlangsung semakin cepat seiring dengan kenaikkan suhu kalsinasi yang ditandai dengan semakin meningkatnya persen kehilangan berat. Proses kalsinasi dolomit optimum dicapai pada suhu $900{ }^{\circ} \mathrm{C}$ selama 4 jam dengan pengurang berat sebesar $46,74 \%$. Berdasarkan perhitungan stoikiometri pengurangan berat 46,74 \% menunjukkan bahwa 97,78 \% dolomit terdekomposisi menjadi $\mathrm{MgO}$ dan $\mathrm{CaO}$. Pembentukan fasa $\mathrm{MgO}$ dan $\mathrm{CaO}$ dari dolomit pada proses kalsinasi melalui dua tahapan yaitu tahapan pembentukan fasa $\mathrm{MgO}-\mathrm{CaCO}_{3}$ pada suhu $700{ }^{\circ} \mathrm{C}$ dan tahapan pembentukan $\mathrm{CaO}$ pada suhu $800{ }^{\circ} \mathrm{C}$ hingga $900{ }^{\circ} \mathrm{C}$.

\section{UCAPAN TERIMAKASIH}

Penulis mengucapkan terimakasih kepada Pusat Penelitian Metalurgi dan Material, Lembaga Ilmu Pengetahuan Indonesia yang telah mendanai penelitian ini melalui kegiatan Kompetensi Inti pada tahun anggaran 2016.

\section{DAFTAR ACUAN}

[1]. A I. Casado et al. "Morphology and Origin of Dolomite in Paleosols and Lacustrine Sequences. Examples from the Miocene of the Madrid Basin”. Sedimentary Geology, vol. 312, pp. 50-62, 2014.

[2]. K. Hips et al. "Dolomitization of Triassic Microbial Mat Deposits (Hungary): Origin of Microcrystalline Dolomite". Sedimentary Geology, vol. 318, pp. 113-129, 2015.

[3]. A.A Olajire. "A Review of Mineral Carbonation Technology in Sequestration of $\mathrm{CO}_{2}$ ". Journal of Petroleum Science and Engineering, vol. 109, pp. 364-392, 2013.

[4]. B.B Joanna et al. "A Novel Method for Simultaneous Determination of Selected Elements in Dolomite and Magnesia by Inductively Coupled Plasma Atomic Emission Spectroscopy with Slurry Sample Introduction". Spectrochimica Acta Part B, vol. 113, pp. 79-83, 2015.

[5]. A. Buasri et al. "The Application of Calcium Oxide and Magnesium Oxide from Natural Dolomitic Rock for Biodiesel Synthesis". Energy Procedia, vol. 79, pp. 562 - 566, 2015.

[6]. L. M. Correia et al. "Characterization and Application of Dolomite as Catalytic Precursor for Canola and Sunflower Oils for Biodiesel Production". Chemical Engineering Journal, vol. 269, pp. 35-43, 2015.

[7]. I.M. Morsi, H.H. Ali. "Kinetics and Mechanism of Silicothermic Reduction Process of Calcined Dolomite in Magnetherm Reactor". International Journal of Mineral Processing, vol. 127, pp. 37-43, 2014.

[8]. H. Galai. "Mechanism of Growth of $\mathrm{MgO}$ and $\mathrm{CaCO}_{3}$ During a Dolomite Partial Decomposition". Solid State Ionics, vol. 178, pp. 1039-1047, 2007. 
[9]. K. Sasaki, et al. "Effect of Natural Dolomite Calcination Temperature on Sorption of Borate onto Calcined Products". Microporous and Mesoporous Materials, vol. 171, pp. 1-8, 2013.

[10]. Ke Wang et al. "Role of $\mathrm{Mg}_{\mathrm{x}} \mathrm{Ca}_{1-\mathrm{x}} \mathrm{CO}_{3}$ on the Physical-Chemical Properties and Cyclic $\mathrm{CO}_{2}$ Capture Performance of Dolomite by Two-step Calcinations". Thermochimica Acta, vol. 614, pp. 199-206, 2015.

[11]. X. Zhang et al. "Reaction Kinetics of Dolomite and Portlandite". Cement and Concrete Research, vol. 66, pp. 11-18, 2014.

[12]. C. Zhang et al. "The Effects of Hydration Activity of Calcined Dolomite (HCD) on the Silicothermic Reduction Process". International Journal of Mineral Processing, vol. 142, pp. 154-160, 2015.

[13]. J. Xie et al. "The Thermochemical Sctivity of Dolomite Occurred in Dolomite-Palygorskite". Applied Clay Science, vol. 119, pp. 42-48, 2016.

[14]. J.M. Valverde et al. "Ca-looping for Postcombustion $\mathrm{CO}_{2}$ Capture: A Comparative Analysis on the Performances of Dolomite and Limestone". Applied Energy, vol. 138, pp. 202-215, 2015.
[15]. J.A. Conesa et al. "Gasification and Pyrolysis of Posidonia Oceanica in the Presence of Dolomite". Journal of Analytical and Applied Pyrolysis, vol. 113, pp. 680-689, 2015.

[16]. L. X. Wei et al. "Preparation of Basic Magnesium Carbonate and Its Thermal Decomposition Kinetics in Air". J. Cent. South Univ. Technol, vol. 18, pp. 1865?1870, 2011.

[17]. P. Gupta and D. Arnab. "The Effect of Composition on The Decomposition Behaviour Of Dolomite Nuggets". Imperial Journal of Interdisciplinary Research (IJIR), vol. 2, pp. 321-324, 2016.

[18]. S. Eko et al. "Pengaruh Ukuran Butiran Terhadap Struktur Kristal pada Proses Kalsinasi Parsial Dolomit”. Majalah Metalurgi, vol. 3, pp.125-132, 2015.

[19]. P. G. Caceres and E. K. Attiogbe. "Thermal Dekomposition of Dolomite and the Extraction of Its Constituents". Mineral Engineering, vol. 10, pp. 1165-1176, 1997.

[20]. P. Engler, et al. "Non-isothermal. In Situ XRD Analysis of Dolomite Decomposition". The Rigaku Journal, vol. 5/No. 2, 1988. 